\title{
Do Policy and Institutional Variables Play a More Significant Role in Attracting Foreign Direct Investment to Eastern Africa than They Do in Other Regions of Sub-Saharan Africa?
}

\author{
Hyeseon Na*
}

\begin{abstract}
The paper aims to assess whether policy and institutional variables are significant factors in attracting foreign direct investment (FDI) to eastern Africa. The assessment is based on the determinants of FDI in a sample of 30 sub-Saharan African (SSA) countries between 2005 and 2016. Employing panel data methodology, I investigate whether policy and institutional variables play a more significant role in attracting FDI to eastern Africa than they do in other SSA countries. The results indicate that these variables are more significant factors for attracting FDI to eastern Africa than they are for the other SSA regions. The paper concludes that eastern Africa's current FDI promotion policies are working. In particular, ensuring a stable macroeconomic situation and a favorable profit tax rate as well as building good institutions have proven to be good tools for attracting FDI to eastern Africa.
\end{abstract}

Keywords: foreign direct investment, policy and institutional variables, eastern Africa

\section{INTRODUCTION}

Foreign direct investment (FDI) inflow into eastern Africa has increased rapidly since 2005, growing from \$US2.6 billion in 2005 to \$US11.7 billion in 2016. ${ }^{1} \mathrm{In}$ addition, the relative share of FDI inflow into eastern Africa has also increased relative to other sub-Saharan African (SSA) countries. From 2001 to 2005, eastern Africa ranked lowest among the four SSA regions, representing about $10 \%$ of total FDI

1. UNCTAD database, http://unctadstat.unctad.org.

\footnotetext{
* Hyeseon $\mathrm{Na}$ is a researcher in the Korea Institute for Industrial Economics and Trade (KIET), Sejong, Korea. E-mail: skgtjs3@naver.com/orkr3@kiet.re.kr.
}

Manuscript received June 9, 2018; out for review June 15, 2018; review completed August 10, 2018; accepted August 14, 2018.

The Korean Journal of Policy Studies, Vol. 33, No. 2 (2018), pp. 41-51.

(C) 2018 by the GSPA, Seoul National University 
inflow into sub-Saharan Africa. ${ }^{2}$ But in the years following, the FDI inflow into the region increased, eventually surpassing that of western Africa, which is made up of resource-rich countries. In 2016, eastern Africa accounted for $26 \%$ of total FDI inflow into sub-Saharan Africa while central, western and southern Africa each constituted $42 \%, 25 \%$, and $6 \%$ of total FDI inflow, respectively. ${ }^{3}$

Compared to other SSA subregions, eastern African countries do not have many natural resources, which are the main attractors of foreign direct investment. Thus, it has been suggested that stable political conditions and favorable business policies explain this increase of FDI inflow into eastern Africa. Most eastern African countries have implemented policies designed to attract FDI, including policies that offer various tax deductions and exemptions, customs duty exemptions, and suppliers' credits and that have established special economic zones and export processing zones. For example, Ethiopia has a comprehensive set of FDI incentives including income tax holidays ranging from one to nine years depending on the business and its location, a 30\% regional income tax deduction, nonfiscal incentives like the right to import machinery and equipment through a suppliers' credit, and 100\% exemption from customs duties and other taxes levied on importation of capital goods and spare parts (KPMG, 2016, p. 31). However, there have been not many studies that definitively show that stable political conditions and favorable business policies are indeed the reason eastern Africa has begun attracting more FDI than other SSA regions. Without evidence, that explanation cannot be used in the promotion of the various incentives offered by governments.

There are some related studies on this issue. One of the key studies, undertaken by Elizabeth Asiedu (2006), analyzes the data of 22 SSA countries for the period 1984-2000. The study concludes that favorable FDI policies and stable institutions, as well as other factors like natural resources and market size, play a significant role in attracting FDI to sub-Saharan Africa. Similarly, Cleeve (2008) finds in an analysis of 16 SSA countries' data for the period 1990-2000 that advantageous FDI policies, especially tax holidays, and a reduction in the level of corruption are significant factors in attracting FDI to sub-Saharan Africa. In addition, in a study of 40 SSA countries for the period 1996-2011, Asamoah and colleagues (2016) show that macroeconomic uncertainty adversely affects FDI inflow and that higher institutional quality increases FDI inflow into SSA countries. Besides these studies, various studies on the impact of policy variables on FDI attraction that use data from other countries similarly conclude that policy variables are significant factors in attracting FDI

2. UNCTAD database, http://unctadstat.unctad.org.

3. UNCTAD database, http://unctadstat.unctad.org. 
(Asiedu \& Villamil, 2000; Buchanan, Le, \& Rishi, 2012; Gani, 2007; Gastanaga, Nugent, \& Pashamova, 1998; Globerman \& Shapiro, 2002; Jadhav, 2012; Javorcik \& Shang-Jin, 2009; Mohamed \& Sidiropoulos, 2010). However, none of these studies directly assesses the importance of policy variables for FDI inflow into eastern Africa. This paper thus aims to fill the gap in the literature.

This study adds to the relevant literature in two ways. First, I analyze not only SSA countries but also eastern African countries. Previous studies focus on sub-Saharan Africa as a whole rather than on specific SSA regions. In this study, I compare the other SSA countries with five major eastern African countries as a means of assessing the relative significance of policy and institutional variables on attracting FDI to eastern Africa.

Secondly, this study takes more recent FDI trends in account by using data for the period 2005-2016. This is especially important considering the recent increase of emerging countries' FDI in Africa. China, India, South Africa, and Brazil have recently expanded their investment in Africa, especially in the manufacturing sectors (World Bank, 2015). This investment behavior contrasts with that of traditional investors like Europe and USA that put their money primarily in resource-based sectors and that have recently decreased investment in manufacturing sectors. In fact, while traditional investors accounted for $72 \%$ of total manufacturing FDI from 2003 to 2006, starting in 2007 new investors represented $50 \%$ of the total (World Bank, 2015). In particular, among new investors, China, India, and regional Africa investors represented about 43\% of total manufacturing FDI between 2011 and 2014 (World Bank, 2015). Thus the impact of policy and institutional variables on FDI in SSA countries and eastern Africa may be different during the recent period compared to the past. In what follows, I describe the variables and the data used, present the model to be estimated and the empirical results, and address the implications of the results.

\section{DESCRIPTION OF THE VARIABLES AND DATA}

Regarding the determinants of FDI, the empirical literature mostly focuses on the host country's "locational advantage" among the three advantages (ownership advantage, locational advantage, internationalization advantage) proposed by Dunning's eclectic theory of what makes a country attractive to foreign firms seeking to invest (Dunning, 1988; Asiedu, 2004). Locational advantages include economic, institutional, and political characteristics like large domestic markets, natural resources, a productive labor force, low labor costs, good infrastructure, a stable 
macroeconomy, and reliable institutions (Asiedu, 2004). Among these variables, this study focuses on policy and institutional variables. In addition, I also include endowment variables that represent a country's attributes that governments cannot readily interfere with in order to assess the relative importance of policy and institutional variables.

The analysis covers 25 countries in sub-Saharan Africa and 5 eastern Africa countries, including Ethiopia and four of the countries that make up the East Africa Community (Rwanda, Kenya, Uganda, and Tanzania) between 2005 and 2016. ${ }^{4}$ The dependent variable, in accordance with previous studies, is the ratio of net FDI inflows to GDP. The data comes from the World Bank's world development indicators (WDI). Other explanatory variables are also obtained from WDI and other resources in the World Bank databank.

Table 1. Summary Statistics, 2005-2016 (25 countries)

\begin{tabular}{l|c|c|c|c}
\hline Variables & Mean & $\begin{array}{c}\text { Standard } \\
\text { Deviation }\end{array}$ & Minimum & Maximum \\
\hline Dependent Variable = 100 *(FDI/GDP) & 5.610 & 7.076 & -5.978 & 42.093 \\
\hline $\begin{array}{l}\text { Policy Variables } \\
\text { macroeconomic instability = inflation rate (\%) }\end{array}$ & 7.934 & 12.458 & -29.691 & 103.823 \\
business promotion policy = profit tax rate & 15.74 & 10.349 & 0 & 38.9 \\
trade promotion policy = CPIA trade sector rating & 3.754 & 0.517 & 2 & 4.5 \\
\hline $\begin{array}{l}\text { Institutional Variable } \\
\text { institutional quality = CPIA institution cluster average }\end{array}$ & 2.976 & 0.500 & 1.6 & 4.1 \\
\hline $\begin{array}{l}\text { Endowment Variables } \\
\text { market size = log(GDP) } \\
\text { natural resources =proportion of fuel exports to } \\
\text { total exports }\end{array}$ & 9.906 & 0.688 & 8.141 & 11.667 \\
\hline
\end{tabular}

* The inflation rate is measured by GDP deflator. In addition, the minimum inflation rate, -29.691 , is the inflation rate of Republic of Congo in 2016 and the maximum inflation rate, 103.823, is the inflation rate of Nigeria in 2011.

4. The following 25 countries are included based on the availability of data: Angola, Benin, Burkina Faso, Cabo Verde, Cameroon, Central African Republic, Comoros, Republic of Congo, Cote d'Ivoire, the Republic of the Gambia, Ghana, Guinea, Guinea-Bissau, Madagascar, Malawi, Mali, Mauritania, Mozambique, Niger, Nigeria, Sao Tomé and Principe, Senegal, Sudan, Togo, Zambia, and Zimbabwe. 
Table 2. Summary Statistics, 2005-2016 (5 countries)

\begin{tabular}{l|c|c|c|c}
\hline Variables & Mean & $\begin{array}{c}\text { Standard } \\
\text { Deviation }\end{array}$ & Minimum & Maximum \\
\hline Dependent Variable = 100 *(FDI/GDP) & 2.860 & 1.713 & 0.113 & 6.480 \\
\hline Policy Variables & & & & \\
macroeconomic instability = inflation rate (\%) & 10.505 & 7.793 & -1.741 & 34.021 \\
business promotion policy = profit tax rate & 25.283 & 4.045 & 20.1 & 33.2 \\
trade promotion policy = CPIA trade sector rating & 3.842 & 0.491 & 3 & 4.5 \\
\hline $\begin{array}{l}\text { Institutional Variable } \\
\text { institutional quality = CPIA institution cluster }\end{array}$ & & & & \\
average & 3.38 & 0.184 & 3 & 3.8 \\
\hline $\begin{array}{l}\text { Endowment Variables } \\
\text { market size = log(GDP) } \\
\text { natural resources = proportion of fuel exports to } \\
\text { total exports }\end{array}$ & 10.311 & 0.324 & 9.549 & 10.719 \\
\hline
\end{tabular}

\section{Description of Explanatory Variables}

\section{Policy Variables}

Following Asiedu (2006), I define policy variables as variables that policy makers can directly alter. Drawing on empirical literature, I include three policy variables related to FDI to measure macroeconomic instability and business and trade promotion policies of the government. Inflation rate, obtained from WDI, is used to measure macroeconomic instability. Though foreign investment is a forward-looking decision, companies looking to make a foreign investment often rely on inflation rate trends from former years in assessing whether to invest rather the current rate. Thus, I used a lagged inflation rate to measure macroeconomic instability. Profit tax rate (\%) is used to measure the extent of business promotion on the part of the host country. Profit tax rate is chosen as a proxy because the government of the host country can directly change it as a way to promote business. In addition, there is data available from the World Bank's Doing Business project regarding the profit tax rate for the period under consideration.

In addition, this study uses the World Bank's CPIA (country policy and institutional assessment) trade rating to measure the host country's trade promotion policy framework. The index assesses how effective the policy framework is in fostering trade in goods and ranges from one to six (a higher score means a more effective 
framework). The index is rated on a global standard among 95 countries rather than among SSA countries.

The hypothesis is that the estimated coefficients of inflation and the profit tax rate should be negative and that that for trade policy should be positive.

\section{Institutional Variable}

The institutional variable in this study assesses how the institutional quality of the host country contributes to attracting FDI. The CPIA public sector management and institutions cluster average from CPIA database is used to measure this variable. The index averages the scores of various public sector management and institutions indexes. The cluster includes indexes of property rights and rule-based governance, quality of budgetary and financial management, efficiency of revenue mobilization, quality of public administration, and level of transparency, accountability, and corruption in the public sector. Though the relevance of each index to FDI differs, the average score can be a proxy encompassing the various institutional bases of government that affect the decision of an organization as to whether to invest in a foreign country. In addition, because of multicollinearity, the average score of the indexes rather than the score of the individual index is used in the model.

The hypothesis is that the estimated coefficient of institutional quality should be positive.

\section{Endowment Variables}

In contrast to the policy variables, endowment variables are defined as attributes that a host country has and that the government cannot directly control. Two variables are used to measure the endowed assets of a host country. GDP is used to measure the domestic market size. As with inflation rate, it is the host country's GDP from previous years rather than the predicted GDP for the year of investment that foreign investors tend to rely on when deciding whether to invest. Thus this study uses a lagged GDP to measure market size. The proportion of fuel exports to total merchandise exports is used to measure the natural resources of host country. Fuel exports are composed of mineral fuels, lubricants and related materials including coal, coke, and briquettes, petroleum, petroleum products and related materials, natural gas, and manufactured gas. The data for these variables were obtained from WDI.

The hypothesis is that the estimated coefficients of GDP and the natural resources of host country should be positive. 


\section{EMPIRICAL ANALYSIS}

The equation to be estimated is

$$
\begin{aligned}
\left(\frac{\mathrm{FDI}}{\mathrm{GDP}}\right)_{i t}= & \alpha+\beta(\text { Endowment Variables })_{i t}+\theta(\text { Policy Variables })_{i t}+ \\
& \gamma(\text { Institutional Variable })_{i t}+\varepsilon_{i t} .
\end{aligned}
$$

Fixed-effects panel estimation is used for analysis. This estimation method can mitigate the problems arising from either pure cross-section or pure time-series analyses and also provide an opportunity to differentiate between the effects of policy changes and other less variable elements related to FDI over time as well as across countries (Gastanaga et al., 1998). In particular, this study assumes that each country has time-invariant variables with time-invariant effects that affect the variables in the model (Williams, 2018). In other words, this study presumes that there are country-specific characteristics that are not included in the model but that nevertheless affect the variables in the model. Thus, to control the variables, this study analyzes countries using a fixed-effects rather than random-effects panel estimation.

Two analyses were conducted to compare the result of 25 SSA countries with the result of 5 eastern African countries. The first analysis employs unbalanced panel data of 25 countries in sub-Saharan Africa between 2005 and 2016. The second analysis conducted an estimation using panel data of 5 eastern African countries over the same period.

The first analysis shows that some of the variables bear out the hypotheses and are highly significant and other variables do not bear out the hypotheses or are not significant. For example, endowment variables, GDP and the natural resources of host country have a positive effect on FDI as predicted and are significant. In other words, market size and natural resource availability promote FDI. The regression result shows that a one unit increase in the natural resources of host country results in a $0.08 \%$ increase in the ratio of FDI to GDP, while a one unit increase in GDP yields a $10.77 \%$ increase in the ratio of FDI to GDP.

In the case of policy variables, the effectiveness of the trade policy framework is significant at the level of 0.05 but has a negative effect on FDI, contrary to the expectation. In other words, the improving the effectiveness of the trade policy framework deters rather than promotes FDI. The regression result shows that a one unit increase in the effectiveness of the trade policy framework results in a $2.56 \%$ decrease in the ratio of FDI to GDP.

Other policy variables including the profit tax rate and inflation have positive coefficients, contrary to the prediction. The profit tax rate is significant at the level 
of 0.1 and inflation is not significant. This shows that a high profit tax might not deter FDI. A high institutional quality rating has a positive effect on FDI as predicted but is not significant even at the level of 0.1. A one unit increase in the profit tax rate results in a $0.21 \%$ increase in the ratio of FDI to GDP.

Table 3. Fixed-Effects Estimation Results Using the Data of SSA Countries (Dependent Variable is $100^{*}(\mathrm{FDI} / \mathrm{GDP})$ )

\begin{tabular}{l|c|c}
\hline Variables & $\begin{array}{c}25 \text { SSA } \\
\text { Countries }\end{array}$ & $\begin{array}{c}\text { 5 Eastern African } \\
\text { Countries }\end{array}$ \\
\hline Intercept & $-104.647^{\star *}$ & 2.889 \\
$(0.026)$ & $(0.885)$ \\
\hline Policy Variables & 0.018 & $-0.047^{* *}$ \\
macroeconomic instability = lag (inflation rate (\%)) & $(0.543)$ & $(0.034)$ \\
business promotion policy = profit tax rate & $0.205^{\star}$ & $-0.480^{* *}$ \\
& $(0.077)$ & $(0.024)$ \\
trade promotion policy = CPIA trade sector rating & $-2.562^{\star *}$ & 0.387 \\
& $(0.049)$ & $(0.45)$ \\
\hline Institutional Variable & & \\
institutional quality = CPIA public sector management and & 2.807 & $2.590^{\star *}$ \\
institution cluster average & $(0.190)$ & $(0.038)$ \\
\hline Endowment Variables & & \\
market size = lag of [log(GDP)] & $10.769^{\star *}$ & 0.212 \\
& $(0.023)$ & $(0.908)$ \\
natural resources = proportion of mineral fuels to total & $0.078^{\star * \star}$ & 0.052 \\
exports & $(0.008)$ & $(0.443)$ \\
\hline $\mathbf{R}^{\mathbf{2}}$ & 0.082 & 0.339 \\
Number of Countries & 25 & 5 \\
Number of Observations & 258 & 55 \\
\hline
\end{tabular}

Note: $p$-values are in parentheses and ${ }^{* * *},{ }^{* *}$ and ${ }^{*}$ denote significance at $0.01,0.05$ and 0.1 levels, respectively

Contrary to the first analysis, the second analysis shows that endowment variables are not significant in the case of the five eastern African countries. In addition, the results of the assessment of the effect of two policy variables likewise contrast with that of the first analysis. The inflation and the profit tax rate have negative effects on FDI as predicted and are statistically significant at the level of 0.05 . The regression result shows that a $1 \%$ decrease in inflation results in a 0.05 increase in the FDI to GDP ratio while a $1 \%$ decrease in the profit tax rate results in a 0.48 percent increase in the ratio of FDI to GDP. Moreover, the effectiveness of the trade 
sector policy framework has a positive coefficient as predicted but is insignificant. The level of institutional quality has a positive effect on FDI as predicted and is significant at the level of 0.05 , contrary to its insignificance in the case of 25 SSA countries. A one score increase in the level of institutional quality results in 2.59 percent increase in the ratio of FDI to GDP

The analysis shows that endowment variables are not significant factors in attracting FDI to eastern African countries, unlike in the case of other SSA countries. But macroeconomic stability, the business promotion policy of host governments, and good institutions were more significant in attracting FDI to eastern African countries than they were in other SSA countries.

\section{CONCLUSION}

The purpose of this study has been to assess whether the policy and institutional variables are significant factors in attracting FDI to eastern Africa. To observe the relative significance of policy and institutional variables to FDI inflow into eastern Africa, I looked at data not only for the major eastern African countries but also other SSA countries.

The results indicate that policy and institutional variables are more significant factors in attracting FDI to eastern African countries than they are for other SSA countries. Though the trade promotion policies of the host government are a significant factor for attracting FDI to the other SSA countries, the value of the coefficients is contrary to the prediction. In other words, a favorable trade environment deters FDI in the case of other SSA countries. In addition, the inflation rate is not a significant factor for attracting FDI to the other SSA countries. But the two policy variables, macroeconomic instability and the business promotion policies of the host government, are significant factors and have the predicted coefficients for eastern African countries. In other words, the low inflation and profit tax rates promote FDI in eastern Africa.

In addition, although high institutional quality is a positive factor for attracting FDI to both the other SSA countries and eastern African countries, the variable is significant only in the case of major eastern African countries but not the other SSA countries at the significance level of 0.1 . This indicates that higher institutional quality is more significant in promoting FDI in eastern Africa than in other SSA regions.

Finally two endowment variables, market size and the availability of natural resources, are important factors in attracting FDI to other SSA countries, but they are not significant catalysts in attracting FDI to eastern African countries. This result 
implies that the market size and natural resources of the host country do not significantly determine FDI inflow into eastern Africa.

These results show that the current FDI promotion policies of eastern African countries are justified. In particular, ensuring a stable macroeconomic situation and offering a favorable profit tax are good tools for attracting FDI to eastern African countries. In addition, considering the significance of the institutional quality variable, building good institutions that guarantee property rights, ensure rule-based governance, engage in good budgetary and financial management, mobilize revenue efficiently, supply high quality public administration and a transparent and accountable public sector also can be a good strategy for attracting FDI to the region.

But in the case of the 25 SSA countries, market size and natural resources have played more significant roles than policy variables. This result shows that many FDI projects in SSA countries are determined by the host country's market size and resources.

Because there is not enough data to study trends in all SSA countries and all eastern African countries, the results of this study do not wholly represent the trends of FDI in SSA countries and eastern Africa. But the result shows that the determinants of FDI are different depending on the SSA subregion. This indicates that the relative effectiveness of each government policy for attracting FDI will be different depending on which subregion the country is located in. Thus, apart from the general endeavors to ensure good institutions, more specific policy efforts for attracting FDI should be emphasized based on region-specific characteristics.

\section{REFERENCES}

Asamoah, M. E., Adjasi, C. K. D., \& Alhassan, A. L. 2016. Macroeconomic uncertainty, foreign direct investment and institutional quality: Evidence from sub-Saharan Africa. Economic Systems, 40(4): 612-621.

Asiedu, E., \& Villamil, A. P. 2000. Discount factors and thresholds: Foreign investment when enforcement is imperfect. Macroeconomic Dynamics, 4(1) :1-21.

Asiedu, E. 2004. Policy reform and foreign direct investment in Africa: Absolute progress but relative decline. Development Policy Review, 22(1): 41-48.

Asiedu, E. 2006. Foreign direct investment in Africa: The role of natural resources, market size, government policy, institutions and political instability. World Economy, 29(1): 63-77.

Buchanan, B. G., Le, Q. V., \& Rishi, M. 2012. Foreign direct investment and institu- 
tional quality: Some empirical evidence. International Review of Financial Analysis, 21:81-89.

Cleeve, E. 2008. How effective are fiscal incentives to attract FDI to sub-Saharan Africa? Journal of Developing Areas, 42(1): 135-153.

Dunning, J. 1988. Explaining international production. London: Unwin Hyman.

Gani, A. 2007. Governance and foreign direct investment links: Evidence from panel data estimations. Applied Economics Letters, 14(10): 753-756.

Gastanaga, V. M., Nugent, J. B., \& Pashamova, B. 1998. Host country reforms and FDI inflows: How much difference do they make? World Development, 26(7): 1299-1314.

Globerman, S., \& Shapiro, D. 2002. Global foreign direct investment flows: The role of governance infrastructure. World Development, 30(11): 1899-1919.

Jadhav, P. 2012. Determinants of foreign direct investment in BRICS economies: Analysis of economic, institutional and political factor. Procedia-Social and Behavioral Sciences, 37:5-14.

Javorcik, B. S., \& Shang-Jin, W. 2009. Corruption and cross-border investment in emerging markets: Firm-level evidence. Journal of International Money and Finance, 28(4): 605-624.

KPMG. 2016. Africa incentive survey 2016. Retrieved on May 30, 2018, https://home. kpmg.com/content/dam/kpmg/pdf/2016/05/africa-incentive-survey-2016.pdf.

Mohamed, S. E., \& Sidiropoulos, M. G. 2010. Another look at the determinants of foreign direct investment in MENA countries: An empirical investigation. Journal of Economic Development, 35(2): 75-95.

Williams, R. 2018. Panel data 4: Fixed effects vs random effects models. University of Notre Dame. Retrieved on July 30, 2018, www3.nd.edu/ rwilliam/stats3/panel04-fixedvsrandom.pdf.

World Bank. 2015. Manufacturing FDI in sub-Saharan Africa: Trends, determinants, and impact. Washington, DC: World Bank.

World Bank. 2018a. Country Policy and Institutional Assessment. Retrieved on May 1, 2018, https://datacatalog.worldbank.org/dataset/country-policy-and-institutional-assessment.

World Bank. 2018b. Doing business 2018. Retrieved on May 1, 2018, http://www. doingbusiness.org.

World Bank. 2018c. World Development Indicators. Retrieved on May 1, 2018, http:// databank.worldbank.org. 
